\title{
The Influence and Research of Innovation and Entrepreneurship on Enterprises
}

\author{
Chen Yanfa \\ (NanChang Institute of Science \& Technology, Nanchang,330108)
}

Keywords: Innovation and entrepreneurship; Corporate performance; High technology; Impact

\begin{abstract}
Under the new situation and new background of "mass entrepreneurship and innovation", China's high-tech enterprises have obtained unprecedented opportunities. At the same time, they are also facing a fierce competitive environment and enormous pressures for survival. How to achieve sustainable development in the market environment where opportunities and challenges coexist has become a topic of common concern for the academic community and the Chinese government. Under the transitional economic situation, China's economic system has gradually shifted from a planned economy to a market economy. China's unique market environment and institutional policies have provided high-tech companies with a large number of business opportunities while also facing severe challenges. In order to acquire the necessary knowledge, technology, opportunities, and resources, high-tech companies gather in the industrial parks and carry out their second venture on the basis of the original enterprises to achieve sustainable development. It can be seen that the company's entrepreneurial activities and corporate agglomeration are the key to improving the performance of high-tech companies.
\end{abstract}

\section{Introduction}

Since it is proposed to vigorously develop innovative entrepreneurship, employment will be promoted through innovative entrepreneurship. This article mainly studies the effect of China's innovative entrepreneurship-driven employment, which can be summarized as "Is innovative entrepreneurship driving employment?", "What is the effect of innovative entrepreneurial employment-led employment?" and "The effect of innovative entrepreneurship-driven employment". Three questions. This paper uses the framework of the classical labor demand theory, and in the short term, the innovative company assumes a monopoly and forms a long-term competitive market. This theoretically shows that innovative entrepreneurship can create labor demand. Furthermore, according to the short, medium, and long-term labor demand characteristics of enterprises, it is proposed that innovative venture-driven employment has job creation effect, market creation effect, impact effect and time lag effect, as well as the impact of innovation and entrepreneurship on enterprises.

\section{Innovative Entrepreneurship}

The so-called innovative entrepreneurship refers to innovative entrepreneurial activities in the entrepreneurial process. Innovative entrepreneurial activities require entrepreneurs to give full play to the spirit of innovation, break through traditional business ideas and organizational forms, guide new market orientation, create new consumer demand, and build new consumer groups, in order to realize the economic and social value of innovative resources.

Innovative entrepreneurship can be divided into technology-driven entrepreneurship and creative-driven entrepreneurship. The former is reflected in the fact that entrepreneurs rely on professional expertise or technology to form their core competitiveness and are successfully brought to market. Creativity-driven entrepreneurship refers to entrepreneurial activities that entrepreneurs explore new business models based on new operational concepts or innovative ideas. After all, most innovative entrepreneurs cannot achieve multiple innovations in technology, products, and models. This article believes that innovation refers to one of the technologies or models. The author believes 
that innovative entrepreneurship must have one of three conditions:

(1) Use new production methods, production techniques or tools;

(2) Produce new products or services;

(3) Adopt new business ideas or business models.

The first two conditions can be summarized as technology-driven entrepreneurship, which can be easily observed and easily imitated in practice. The third condition is a prerequisite for creatively driven entrepreneurship. A successful creative-driven entrepreneurship can greatly promote productivity. The improvement. Contrary to innovative entrepreneurship, traditional entrepreneurial entrepreneurship. Although different scholars have different explanations for the connotation of traditional entrepreneurial ventures, the traditional entrepreneurial types all have common features: simple repetition of existing business behaviors in minor innovations or slight changes in existing ones in order to gain market share Share. Compared with traditional entrepreneurial ventures, although innovative startups have to bear higher initial costs in the early stages of their ventures, start-up companies that enter growth stages will have stronger competitive advantages, higher barriers to entry, and monopolistic advantages. On the contrary, though traditional startups have lower initial costs, they can easily be imitated and lack competitive advantages.

\section{Innovation and Entrepreneurship Drive Employment}

With the slowdown of the domestic economic growth, excess production capacity has exposed the drawbacks of the traditional business model. The traditional model of entrepreneurship has become less and less effective for employment promotion. Today's and future China's entrepreneurial ventures are no longer the general sense of entrepreneurship. Instead, they should be innovative entrepreneurial ventures that drive entrepreneurship through innovation and use entrepreneurship to drive entrepreneurship. Employment (Wang Yongchang, 2015). Wang Qi and Lai Desheng (2015) compared the model characteristics of innovation in the United States, Germany, the Republic of Korea, India, and Israel to drive entrepreneurship and employment. It was found that: excessive government intervention, complex enterprise creation procedures, lack of innovation in SMEs, and lack of innovation and entrepreneurship education These are the main factors that affect China's innovation and entrepreneurial employment, and need to be adjusted from the institutional mechanism to expand the entrepreneurial employment effect of technological innovation.

Colleges are the suppliers of knowledge and technology. At the same time, a large number of graduates' employment problems need to be implemented each year. Therefore, actively encouraging college students to engage in innovative entrepreneurship is a breakthrough to solve the employment difficulties of college students. Yang Xiaohui (2015) proposed to encourage college students to start their own businesses. First of all, it is necessary to position innovative education in universities in the cultivation of innovative talents. It is necessary to focus on establishing a national framework for the quality structure of innovative talents, building a theoretical system of entrepreneurship education with Chinese characteristics, and improving the operating system of entrepreneurship education in colleges.

It can be seen from this that domestic scholars have just started the research on innovative entrepreneurship-driven employment, and there are few research results from the empirical point of view.

\section{The Assumption of the Relationship between Innovation, Entrepreneurship and Performance}

The relationship between the company's entrepreneurial and corporate performance is a hot topic in the field of entrepreneurial research. Although the researchers have always been inconsistent with the relationship between the two, most scholars believe that corporate entrepreneurship and corporate performance are positively correlated.

Zahra used regression analysis to prove that corporate entrepreneurship has a positive impact on corporate performance. Dess also proved that the company's entrepreneurial activity has a positive impact on corporate performance. In the process of research, it added environmental dynamics as a 
controlling variable to give support and in-depth discussion. Wiklund proved that the company's entrepreneurial activity has a positive influence on the performance of the company's long-term performance. In this process, a longitudinal study was used to deeply compare the impact of the company's entrepreneurial venture on short-term performance and long-term performance, and finally reached a conclusion. Zahra and Nielsen conducted an empirical study on international companies. The results show that corporate entrepreneurial activities can improve corporate performance.

Matsuno et al. found through a lot of empirical research that in a market economy environment, corporate entrepreneurial activity has a positive effect on corporate performance. Corporate entrepreneurship is constrained by the market environment, and at the same time it can seek breakthrough development in the market to enhance corporate performance, especially In the uncertain external environment, the market activity is positively related to the company's entrepreneurship. The more active the market, the higher the success rate of the company's entrepreneurship, which in turn enables the company's overall strategy to be expanded and transformed into a realistic corporate performance.

We believe that corporate entrepreneurship as an enterprise innovation practice can effectively improve the overall strength and performance of entrepreneurial performance.

Jointly put forward a point of view: Corporate industry activities will reduce the performance of companies. This result stems from the fact that four people analyzed a company's entrepreneurial activities based on a large number of empirical studies and found that it was constrained and influenced by other factors during the company's entrepreneurial activities. These factors included changes in the external market environment and increased risks. However, the company's ability to assume has not improved. Therefore, the company's entrepreneurial activity under such conditions is not conducive to improving corporate performance. On the contrary, it will also reduce the level of corporate performance.

\section{The Influence of the Company's Innovation and Entrepreneurship on the Performance of High-Tech Enterprises}

Assume that we have constructed two models (Model 1 and Model 2). Model 1 is a basic model that only reflects the impact of control variables (corporate age, firm size, employee qualifications) on firm performance. From the results of Model 1, it can be seen that except for the age of employees, other control variables have no significant effect on the performance of the company. Model 2 adds a degree of innovation variable to Model 1 to test the impact of the degree of innovation in high-tech companies' entrepreneurial activity on the performance of high-tech companies. The results of the study are shown in Table 1.

Table 1. The Regression Model of the Effect of Innovation Degree on Firm Performance

\begin{tabular}{|c|c|c|c|c|}
\hline \multirow{2}{*}{ Variate } & \multicolumn{4}{|c|}{ Dependent variable } \\
\cline { 2 - 5 } & Model 1 & VIF & Model 2 & VIF \\
\cline { 2 - 5 } & $.390 * * *$ & 1.075 & $.379 * * *$ & 1.077 \\
\hline Enterprise age & -.008 & 1.045 & -.021 & 1.047 \\
\hline Staff qualification & .077 & 1.058 & .062 & 1.060 \\
\hline Innovation degree & & & $.304 * * *$ & 1.007 \\
\hline $\mathrm{R}^{2}$ & .171 & & .263 & \\
\hline Ajust R $^{2}$ & .146 & & .232 & \\
\hline$\Delta \mathrm{R}^{2}$ & & & .092 & \\
\hline F value & $6.799 * * *$ & & $8.722^{* * *}$ & \\
\hline
\end{tabular}

Notes: ${ }^{*} \mathrm{p} \leq 0.05$ (two sides check); ${ }^{* *} \mathrm{p} \leq 0.01$ (two sides check); ${ }^{* * *} \mathrm{p} \leq 0.001$ (two sides check)

After adding the innovation degree variable, the regression coefficient of innovation degree to firm performance was 0.304 , and the significance level was $\mathrm{p} \leq 0.001$, F value was 8.722 ( $\mathrm{p} \leq$ 0.001 ), and R2 value was increased by 0.092 , demonstrating that model 2 was more plausible than model 1, and the rate has improved. Therefore, suppose $\mathrm{H} 1$ passes the test that the level of 
innovation has a positive effect on firm performance.

In addition, in order to test whether the model has multiple collinearity problems, the variance inflation factor (VIF) of each variable was calculated in the linear regression analysis. The results show that all variables in model 1 and model 2 are The VIF values are all less than 1.1, which proves that the model does not have multiple collinearity problems and the tolerance is high.

\section{Conclusion}

This article studies the company's entrepreneurship from the three dimensions of innovation level, risk activity and strategy update. In addition, according to the characteristics of high-tech enterprises, this paper discusses the driving factors of corporate agglomeration behavior from three perspectives: knowledge, opportunity and resources. Among them, knowledge-driven agglomeration refers to the agglomeration behavior of the enterprise for the purpose of obtaining and utilizing knowledge within the cluster due to the needs of knowledge and technology, including the identification, sharing, and transformation of knowledge; opportunity-driven agglomeration refers to the enterprise. In order to obtain entrepreneurial opportunities, the agglomeration behaviors in industrial parks include the identification, utilization, and integration of entrepreneurial opportunities; resource-driven agglomeration refers to the use of high-tech industrial parks for natural resources to acquire business opportunities and improve business performance of aggregation behavior.

\section{Reference}

[1]Ehrenberger M, Koudelkova P, Strielkowski W. Factors Influencing Innovation in Small and Medium Enterprises in the Czech Republic[J]. Periodica Polytechnica Social \& Management Sciences, 2015.

[2]Cáceres R, Guzmán J, Rekowski M. Firms as source of variety in innovation: influence of size and sector[J]. International Entrepreneurship \& Management Journal, 2011, 7(3):357-372.

[3]Gupta P D. Firm growth and its determinants[J]. Journal of Innovation \& Entrepreneurship, 2013, 2(1):1-14.

[4]Orchard S. Entrepreneurship and the Human Capital of Organizational Innovation: The Intrapreneur[J]. 2015.

[5]Edwards-Schachter M, García-Granero A, Sánchez-Barrioluengo M, et al. Disentangling competences: Interrelationships on creativity, innovation and entrepreneurship[J]. Thinking Skills \& Creativity, 2015, 16:27-39.

[6]Zhang P, Huang Z, Gao X. Research on Relationship Between Political Connections and Entrepreneurial Enterprise's Innovation Capability: The Influence of TMT's Characteristics[J]. Science of Science \& Management of S \& T, 2014.

[7]Wen-Jun Y U, Chun-Ming Y E, Management S O. The Impact Study of Private Enterprise Social Capital and Entrepreneurship on Innovation Performance[J]. Industrial Engineering \& Management, 2013.

[8]Arora R. Perspectives of Entrepreneurship and Its Impact on Stakeholders' Co-Creation[M]// Entrepreneurial Challenges in the 21st Century. Palgrave Macmillan UK, 2016.

[9]Newth J. Social Enterprise Innovation in Context: Stakeholder Influence through Contestation[J]. Entrepreneurship Research Journal, 2016, 6(4):369-399.

[10]Lahi A, Elenurm T. Catalysts and Barriers of Open Innovation for SMEs in Transition Economy[C]// 2014.

[11]Xiao-Ping L I, Xiao-Ke L I. Does Entrepreneurship Promote Business Innovation -an analysis on the ownership heterogeneity of provincial industrial enterprises[J]. Journal of Guizhou University of Finance \& Economics, 2017.

[12]Zheng Y. On the Influence of Innovation Policies on Enterprise Enhancing Its Innovation Competitive Power-Mediation Model Based on Non Parameter Percentile[J]. Journal of Minjiang University, 2017. 